\title{
MICROWAVE IRRADIATION OPTIMIZATION FOR EFFICIENT LIGNIN REMOVAL FROM COCOA SHELL WASTE USING ALKALI
}

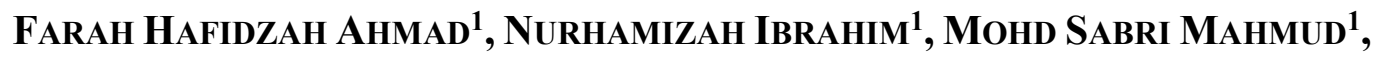 \\ Waleed Ali ${ }^{1}$, Mohd BiJarimi Mat Piah ${ }^{1}$, Suriyati Salleh ${ }^{2}$, \\ AND SAID NURDIN ${ }^{3}$ \\ ${ }^{1}$ Department of Chemical Engineering, College \& Natural Resources Engineering, \\ ${ }^{2}$ Faculty of Chemical and Process Engineering Technology, \\ Universiti Malaysia Pahang, Gambang, 26300 Kuantan, Pahang, Malaysia \\ ${ }^{3}$ Chemical Engineering Department, Faculty of Engineering-Syiah Kuala University, \\ Darussalam, Bandar Acheh, 23111 Indonesia \\ "Corresponding author: mohdsabri@ump.edu.my
}

(Received: $10^{\text {th }}$ September 2020; Accepted: $5^{\text {th }}$ March 2021; Published on-line: $4^{\text {th }}$ July 2021)

\begin{abstract}
This paper reports a study to determine the optimum conditions of microwave in assisting alkali treatment for removing lignin from cocoa shell waste (CSW). The CSW was mixed with $5 \%$ of $\mathrm{NaOH}$ solution at the ratio of $1: 10$ of weight to volume of the alkaline before being irradiated in a microwave oven. Various microwave powers $(200-400 \mathrm{~W})$, temperature settings $\left(60-80{ }^{\circ} \mathrm{C}\right)$ and irradiation times $(10-20 \mathrm{~min})$ were tested on 15 samples set by the Box-Behnken design. The lignin removal was analysed using a $72 \%$ sulfuric acid treatment method. A quadratic equation was employed to the response surface and statistical analysis conducted to confirm the adequacy of the model. The plots show that the optimum microwave conditions are $400 \mathrm{~W}, 76^{\circ} \mathrm{C}$ and $19 \mathrm{~min}$, which were capable to remove $86.57 \%$ of lignin. Thermogravimetric analysis and micrographs revealed different decomposition temperature of lignin and morphology of extensively-pored surface of treated CSW, respectively.
\end{abstract}

ABSTRAK: Kajian ini berkaitan penentuan keadaan optimal ketuhar gelombang mikro bagi membantu membuang lignin daripada sisa kulit biji koko (CSW) menggunakan rawatan alkali. CSW dicampurkan dengan larutan $\mathrm{NaOH} 5 \%$ pada nisbah 1:10 berat kepada isipadu larutan alkali sebelum campuran dipanaskan ke dalam ketuhar gelombang mikro. Pelbagai ujian dibuat pada ketuhar gelombang mikro seperti tenaga (200-400 W), suhu ketuhar $\left(60-80^{\circ} \mathrm{C}\right)$ dan masa pemanasan $(10-20 \mathrm{~min})$ ke atas 15 sampel mengikut reka bentuk Box-Behnken. Kadar pembuangan lignin ditentukan dengan menggunakan kaedah rawatan larutan asid sulfurik berkepakatan $72 \%$. Persamaan kuadratik telah digunakan ke atas permukaan respon dan analisis statistik telah dilakukan bagi memastikan kesesuaian model. Plot-plot menunjukkan keadaan optima ketuhar gelombang mikro adalah pada $400 \mathrm{~W}, 76^{\circ} \mathrm{C}$ dan 19 min iaitu berupaya menyingkirkan sebanyak $86.57 \%$ lignin. Analisis thermogravimetri dan mikrograf masing-masing menunjukkan perbezaan suhu penguraian lignin dan morfologi permukaan CSW yang dirawat didapati berliang dengan banyaknya.

KEYWORDS: cocoa shell waste; microwave assisted; alkali treatment; lignin removal; non-wood fibers; response surface methodology 


\section{INTRODUCTION}

By-product discarded from food industries may harm environment in large quantities [1]. Cocoa (Theobroma cacao) shell waste (CSW) is an example of the by-products that is usually used, among others, for dietary, food additives, fuel burning, or fertilizer in order to prevent accumulation [2-6]. An alternative approach to add value is by utilizing CSW as non-wood for bio-composite preparation. However, there is a drawback that needs to be considered since CSW is mainly composed of cellulose, lignin, hemicelluloses, pectin, and wax. Weak binding between fiber and polymer due to moisture absorption [7], low impact strength [8], faced dimension instability for fibers composites [9] and low microbial resistance [10] of CSW application are reported that are mainly caused by the presence of hydroxyl groups from lignin in its fiber. Therefore, reduction of lignin is essentially required.

Pre-treatment using alkali is a vital step in converting the lignocellulosic material into less wood material. Several studies suggested the use of microwave heating to accelerate the pre-treatment process due to some advantages over conventional heating $[11,12]$. In particular, microwave-assisted alkaline pre-treatment for hydrolysis and fermentation increase cellulose breakdown and the activity of the reactions [13]. Interface of fibers with lower hydroxyl group will bond with matrix better and enhance strengths of the composites $[9,14]$. Sodium hydroxide $(\mathrm{NaOH})$ is an effective alkaline in breaking down lignin structure $[15,16]$ that leads to an increase in surface area and pore volume in the substrate. Meanwhile, microwave radiation results in rapid heating due to interaction between an irradiated object and electromagnetic field [17,18]. Thus, this high efficiency of treatment eases the implementation $[19,20]$ of breaking down lignocellulosic material bonding.

Several studies reported on the optimization of treatment process parameters for other agricultural wastes. For instance, Sombatpraiwan et al. [17] conducted microwave -assisted on cassava rhizome by varying microwave power (300-900 W), irradiation time (5-15 min), and $\mathrm{NaOH}$ concentration $(3 \%-7 \% \mathrm{w} / \mathrm{v})$. It was found that optimal conditions for lignin removal were $840 \mathrm{~W}$ microwave, $9 \mathrm{~min}$, and 3\% w/v NaOH. Lai et al. [21] found that $22.38 \%$ lignin removal was optimal at 900 watt, $100{ }^{\circ} \mathrm{C}$, and $80 \mathrm{~min}$ from a two-level factorial analysis on the range of microwave power, temperature and heating duration range spanning from 500 to $900 \mathrm{watt}, 80$ to $100{ }^{\circ} \mathrm{C}$ and 40 to $80 \mathrm{~min}$ on oil palm trunk.

The aim for this study is to determine optimal microwave-assisted alkali treatment condition on CSW. The pre-treatment parameters are microwave power, temperature setting and irridiation time, which were varied between $200-400 \mathrm{~W}$ and $60-80^{\circ} \mathrm{C}$ for $10-20$ min, respectively. This treatment was optimized by using the Box-Behnken design (BBD), response surface methodology (RSM).

\section{MATERIALS AND METHODS}

\subsection{Assisted Alkali Treatment}

CSW samples were mixed to $5 \%$ of $\mathrm{NaOH}$ at 1: 10 according to the ratio of sample weight to volume of the alkaline. The microwave was set to the ranges of $200-400 \mathrm{~W}, 60$ $-70{ }^{\circ} \mathrm{C}$ and $10-15 \mathrm{~min}$ for power, temperature and time of irradiation, respectively. All these treatment conditions were designed based on BBD using Design Expert Software version 7 .

After the treatment, mixtures were filtered to recover solid residue. The residue was rinsed with distilled water to remove the alkali solution and followed by the addition of $5 \%$ 
acetic acid solution in dropwise. Then, the slightly acidic residue was rinsed again with distilled water until neutral $\mathrm{pH}$ was achieved. The treated CSW was dried at $105{ }^{\circ} \mathrm{C}$ until constant weight was achieved.

\subsection{Experimental Design}

BBD was used to optimize microwave parameters as the factor in assisting the caustic removal of lignin from CSW via 15 experiments in random order with three replications at the centre point. The design of experiment was of three-factor and two-level factorial BoxBehnken design (BBD) [17]. The three factors were microwave power (X1), temperature (X2), and treatment time (X3) with low, moderate, and high levels factor as represented by $-1,0$, and 1 as shown in Table 1 . Percentage of lignin removal was the response variable. 3D surface plots were generated through fitting of a quadratic polynomial between the factors and the response.

Table 1 Experimental levels of three independent variables

\begin{tabular}{ccccc}
\hline Factors & Units & \multicolumn{3}{c}{ Factor Levels } \\
\cline { 3 - 5 } & & $\mathbf{- 1}$ & $\mathbf{0}$ & $\mathbf{1}$ \\
\hline Microwave Power & $\mathrm{W}$ & 200 & 300 & 400 \\
Temperature Setting & ${ }^{\circ} \mathrm{C}$ & 60 & 70 & 80 \\
Irradiation Time & $\mathrm{min}$ & 10 & 15 & 20 \\
\hline
\end{tabular}

\subsection{Lignin Removal Determination}

Two grams of untreated / treated CSW samples were mixed with $15 \mathrm{~mL}$ of $72 \%$ sulphuric acid in a flask. The mixtures were vigorously stirred at ambient temperature for 2 hours. Then, hot distilled water was added to the mixtures to reduce acid concentration up to $4 \%$. The mixture was heated immediately in a water bath at $100{ }^{\circ} \mathrm{C}$. After 4 hours, the $\mathrm{CSW}$ was filtered and rinsed with hot distilled water to neutralize $\mathrm{pH}$ before it was dried at $105{ }^{\circ} \mathrm{C}$ until constant weight was achieved. The amounts of lignin removal for all the samples were determined by using Equation (1).

$$
\text { lignin removal } \%=\frac{\text { initial CSW sample }- \text { treated CSW sample }}{\text { initial CSW sample }} \times 100 \%
$$

\subsection{Analyses of Thermogravimetry and Morphology}

The degradation of the treated CSW sample was measured by thermogravimetric analysis (TGA) using the Hitachi STA-7200 thermal analyser. CSW samples ( $5 \mathrm{~g}$ ) were placed in alumina pan and heated from ambient temperature up to $1000{ }^{\circ} \mathrm{C}$ at a heating rate of $10^{\circ} \mathrm{C} \mathrm{min}^{-1}$ under nitrogen flow blanketing. The sample weights were obtained as a function of temperature. The effect of treatment on surface morphology of CSW were observed via scanning electron microscopy (SEM). The plate with CSW samples was and placed at LEO 1450 VP SEM for the analysis with magnifications of 5000 times.

\section{RESULTS AND DISCUSSION}

\subsection{Effect of Process Parameters on Lignin Removal}

Box-Behnken design (BBD) was used to determine the samples and plot the responses surface. Fifteen runs were carried out to obtain the results in Table 2. In particular, experimental run\#8 $\left(400 \mathrm{~W}, 70{ }^{\circ} \mathrm{C}, 20 \mathrm{~min}\right)$ achieved the highest lignin removal, while run\#14 (200 W, $\left.70{ }^{\circ} \mathrm{C}, 10 \mathrm{~min}\right)$ obtained the lowest one. 
Table 2: Lignin removal of CSW samples using different process parameters

\begin{tabular}{c|c|c|c|c|c}
\hline Run & $\begin{array}{c}\text { Microwave } \\
\text { Power Level }\end{array}$ & $\begin{array}{c}\text { Temperature } \\
\text { Level }\end{array}$ & $\begin{array}{c}\text { Irradiation } \\
\text { Time Level }\end{array}$ & $\begin{array}{c}\text { Lignin Removal } \\
\text { (\%) Experimental }\end{array}$ & $\begin{array}{c}\text { Lignin Removal } \\
\text { (\%) Predicted }\end{array}$ \\
\hline 1 & +1 & -1 & 0 & 63.07 & 66.06 \\
2 & 0 & -1 & -1 & 61.79 & 57.54 \\
3 & 0 & +1 & -1 & 54.47 & 53.80 \\
4 & +1 & +1 & 0 & 83.01 & 82.42 \\
5 & -1 & 0 & +1 & 50.19 & 48.94 \\
6 & 0 & -1 & +1 & 61.43 & 62.14 \\
7 & 0 & +1 & +1 & 64.17 & 68.41 \\
8 & +1 & 0 & +1 & 86.34 & 82.69 \\
9 & 0 & 0 & 0 & 73.52 & 69.86 \\
10 & -1 & +1 & 0 & 33.75 & 30.76 \\
11 & -1 & -1 & 0 & 43.97 & 44.55 \\
12 & +1 & 0 & -1 & 74.67 & 75.93 \\
13 & 0 & 0 & 0 & 67.12 & 69.86 \\
14 & -1 & 0 & -1 & 32.87 & 36.52 \\
15 & 0 & 0 & 0 & 68.94 & 69.86 \\
\hline
\end{tabular}

The effect of three process variables on lignin residue was generally significant as confirmed by the high $\mathrm{R}^{2}$ value $(\mathrm{R}=0.97)$. The quadratic equation established the level of lignin removal as a function of different microwave power, temperature setting and irradiation time. All the terms regardless of their significance are included in Equation (2). After considering the significance of the terms, Equation (3) was obtained where the symbols were denoted as $\mathrm{A}=$ microwave power, $\mathrm{B}=$ temperature setting and $\mathrm{C}=$ irradiation time.

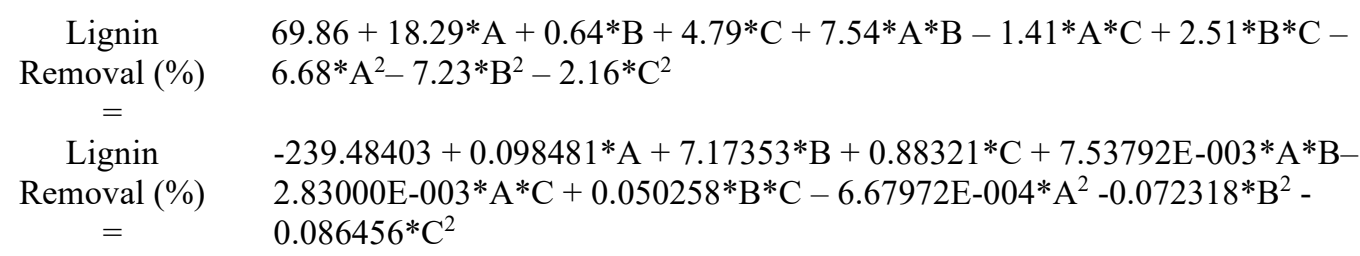

Fig. 1(a) shows the actual experimental data versus predicted data of lignin residue (\%) which was generated from the quadratic equation model. The normal probability plot was also presented in Fig. 1(b). The plot indicates that the internal studentized residual (different between actual and predicted data) follow a normal distribution and form an approximately linear line.

Table 3 summarizes the F-test and p-value that were used to assess the significance of the coefficients of the model for respective parameters and the interaction strength among the parameters. P-values that are less than 0.05 indicate significance of model terms, which are shown by $\mathrm{A}, \mathrm{C}, \mathrm{AB}, \mathrm{A}^{2}$ and $\mathrm{B}^{2}$. Oppositely, the values greater than 0.1 indicates their insignificance. The "Lack of Fit F-value" (LOF) of 2.61 implies that the LOF is not significant relative to the pure error, thus good model, which means the terms are adequate to fit the model. Meanwhile, the fitness, $\mathrm{R}^{2}$ and further-refined fitness, $\mathrm{Adj} \mathrm{R}^{2}$ are 0.970 and 
0.916, respectively, which indicate that the estimated model that fits the experimental data is reasonable.

Fig. 1(a) shows the actual experimental data versus predicted data of lignin residue (\%) which was generated from the quadratic equation model. The normal probability plot was also presented in Fig. 1(b). The plot indicates that the internal studentized residual (different between actual and predicted data) follow a normal distribution and form an approximately linear line.

Table 3: Statistical analysis

\begin{tabular}{cccccc}
\hline $\begin{array}{c}\text { Source of } \\
\text { variation }\end{array}$ & $\begin{array}{c}\text { Sum of } \\
\text { squares }\end{array}$ & $\begin{array}{c}\text { Degree } \\
\text { of } \\
\text { freedom }\end{array}$ & $\begin{array}{c}\text { Mean } \\
\text { square }\end{array}$ & $\begin{array}{c}\mathbf{F} \\
\text { Value }\end{array}$ & $\begin{array}{c}\text { p-value } \\
\text { probability }\end{array}$ \\
\hline $\begin{array}{c}\text { Model } \\
\text { A-microwave } \\
\text { power }\end{array}$ & 3461.364 & 9 & 384.596 & 17.970 & $0.0027 \mathrm{a}$ \\
$\begin{array}{c}\text { B-temperature } \\
\text { C-time }\end{array}$ & 2676.254 & 1 & 2676.254 & 125.049 & $<0.0001 \mathrm{a}$ \\
AB & 183.302 & 1 & 3.302 & 0.154 & $0.7106 \mathrm{~b}$ \\
AC & 227.281 & 1 & 183.792 & 8.588 & $0.0326 \mathrm{a}$ \\
BC & 8.009 & 1 & 227.281 & 10.620 & $0.0225 \mathrm{a}$ \\
$\mathrm{A}^{\wedge} 2$ & 25.259 & 1 & 8.009 & 0.374 & $0.5675 \mathrm{~b}$ \\
$\mathrm{~B}^{\wedge} 2$ & 164.746 & 1 & 164.746 & 7.180 & $0.3269 \mathrm{~b}$ \\
$\mathrm{C}^{\wedge} 2$ & 193.104 & 1 & 193.104 & 9.023 & $0.0392 \mathrm{a}$ \\
Residual & 17.249 & 1 & 17.249 & 0.806 & $0.0300 \mathrm{a}$ \\
Lack of Fit & 107.008 & 5 & 21.402 & & $0.4105 \mathrm{~b}$ \\
Pure Error & 85.259 & 3 & 28.420 & 2.613 & $0.2888 \mathrm{~b}$ \\
Correction total & 21.750 & 2 & 10.875 & & \\
$\mathrm{R}^{2}$ & 3568.373 & 14 & & & \\
Adj $\mathrm{R}^{2}$ & 0.970 & & & & \\
\hline
\end{tabular}

Value of $\mathrm{p}$-Value $<0.0500$ indicate model terms are significant

asignificant

${ }^{\mathrm{b} N o t}$ Significant
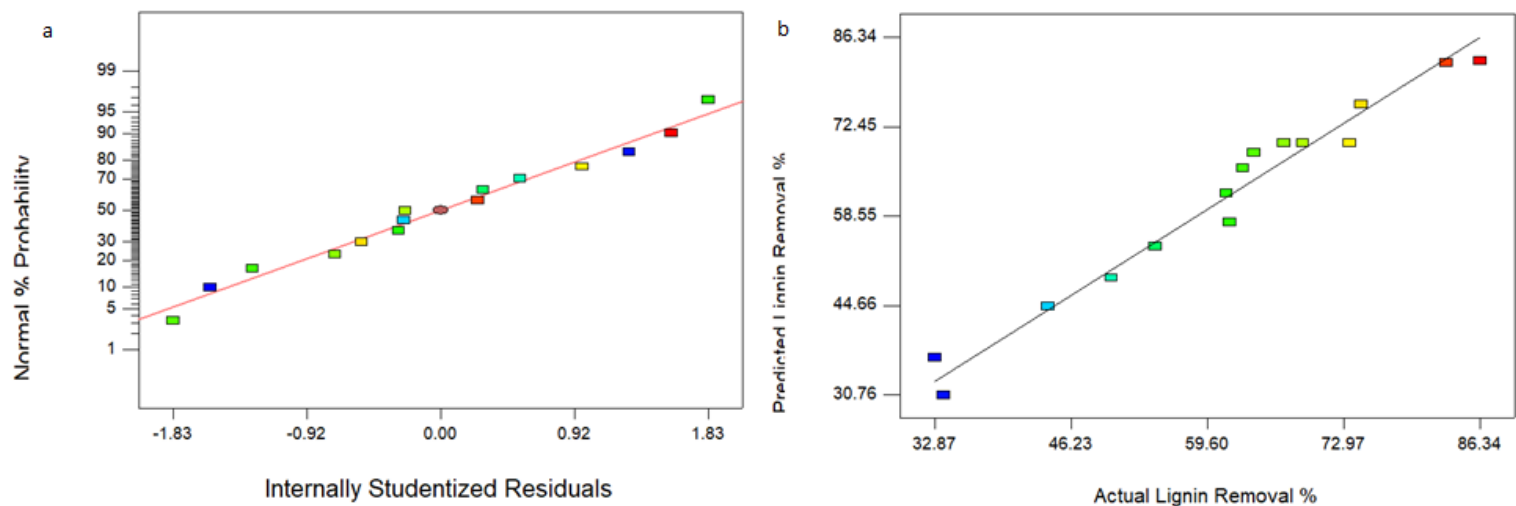

Fig. 1: (a) Correlation of normal probability of internal studentized residuals, and (b) actual conversions and values predicted by model. 


\subsection{Effect of Individual Parameters: Microwave Power, Temperature Setting and Irradiation Time on Lignin Removal}

The effects of three microwave parameters on the alkaline treatment of CSW are shown in Fig. 2. The lignin removal was improved significantly by the increase of microwave power from $200 \mathrm{~W}$ to $400 \mathrm{~W}$ in Fig. 2(a). In particular, CSW treatment at $80{ }^{\circ} \mathrm{C}$ for about 20 minutes increased the lignin removal up to $40 \%$ by raising microwave power from $200 \mathrm{~W}$ to $250 \mathrm{~W}$. These results indicate that the microwave power probably help break down the structure of CSW. However, upon increase of temperature and time at $200 \mathrm{~W}$ microwave power, the lignin removal only slightly changed as shown in Fig. 2(b) and (c). Upon the increase of temperature from $60{ }^{\circ} \mathrm{C}$ to $70{ }^{\circ} \mathrm{C}$, the lignin removal approximately increased up to $14 \%$ and reach similar percent removal started from $75^{\circ} \mathrm{C}$ to $80{ }^{\circ} \mathrm{C}$ when $\mathrm{CSW}$ exposing $400 \mathrm{~W}$ of irradiation for about 20 minutes. Lignin removal on CSW at $400 \mathrm{~W}$ irradiation and temperature setting about $80^{\circ} \mathrm{C}$ which varying irradiation time was apparently not effective. Based on the observation in Fig. 2(c), the percentage of lignin removal only improved 7\% when the time was increased from 10 to 15 minutes and as of beyond 15 minutes the lignin removal started to decline as the percentage removing was too small. Since the longer irradiation time was less effective for reducing the lignin content, shorter duration would be more economical due to low power consumption [21]. Duan et al. [22] had studied the effects of microwave temperature, microwave time, and hydrochloric acid concentration on characteristics and pyrolysis behaviour of lignin. Their results show that microwave temperature applied the most significant influence on lignin conversion at $600 \mathrm{~W}$. Thus, at high microwave power, temperature is elevated. Response surface area reveals the effect of temperature at different microwave power.
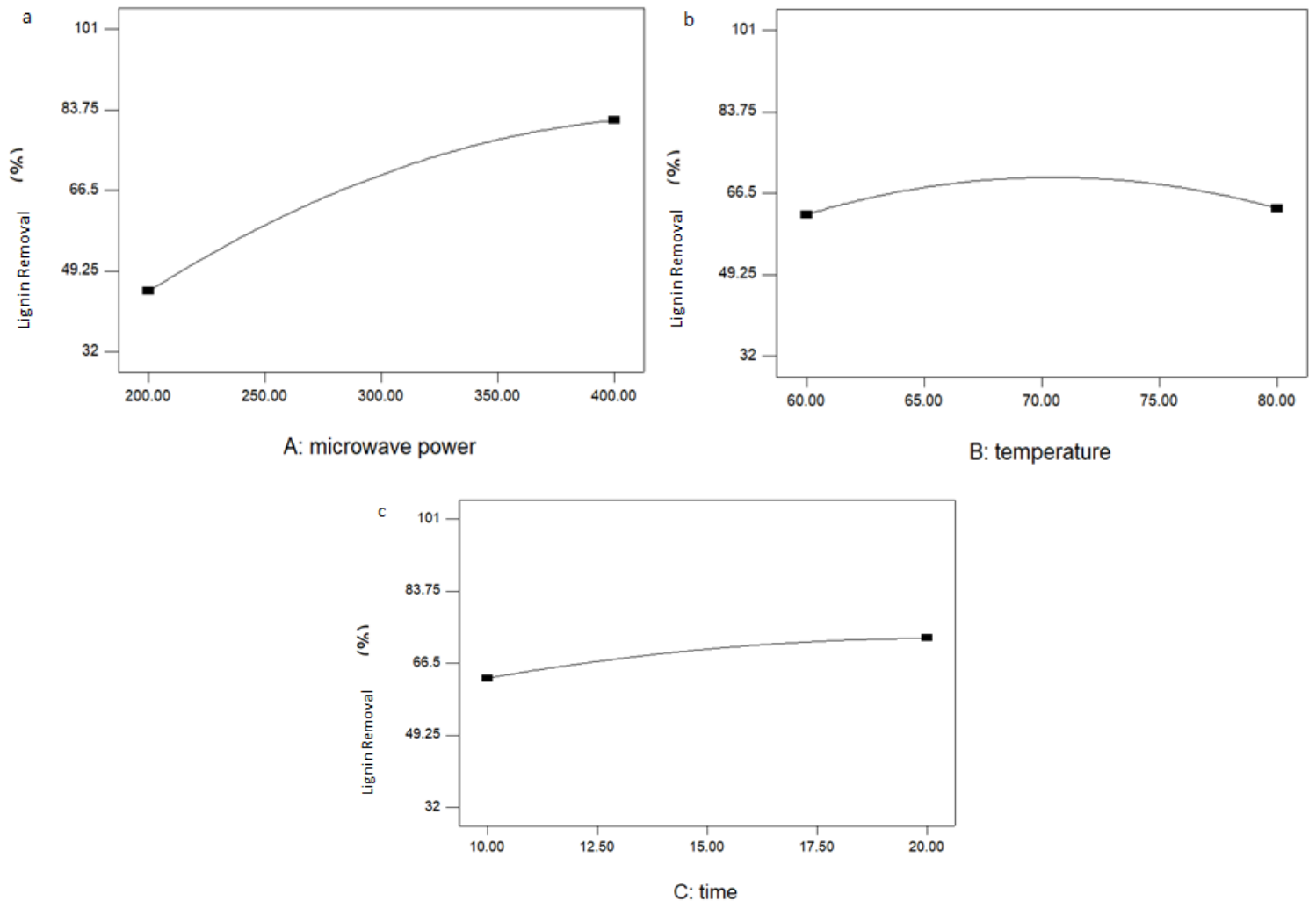

Fig. 2: (a) Effect of various individual parameters: microwave power, (b) temperature setting and (c) irradiation time on the lignin removal from CSW.

One parameter was varied while others are kept constant at their centre point. 


\subsubsection{Response Surface of Lignin Removal}

Figure 3 illustrates the plots of interaction between the three microwave parameters on the lignin removal from CSW. These plots exhibit correlation between two variables, with one variable fixed at various levels. The increase of lignin removal had been affected dominantly by the increase of microwave power and temperature as compared to irradiation time. These results conform to the finding made by Vardhini et al. [23] on banana fibre. Among the interaction between respective parameters, the irradiation time was observed to be less effecting in achieving the objective of removing lignin. Furthermore, combination of high microwave power and temperature significantly increased the lignin removal. Overall, the microwave parameters that maximally removed lignin from the CSW under caustic mixture for this study (Fig. 2a, b, and c) were $400 \mathrm{~W}, 76{ }^{\circ} \mathrm{C}$ and 19 min where $86.57 \%$ lignin was removed. Further increase of microwave power and temperature may find an optimum point but the study was continued due to the limitation of our microwave oven.
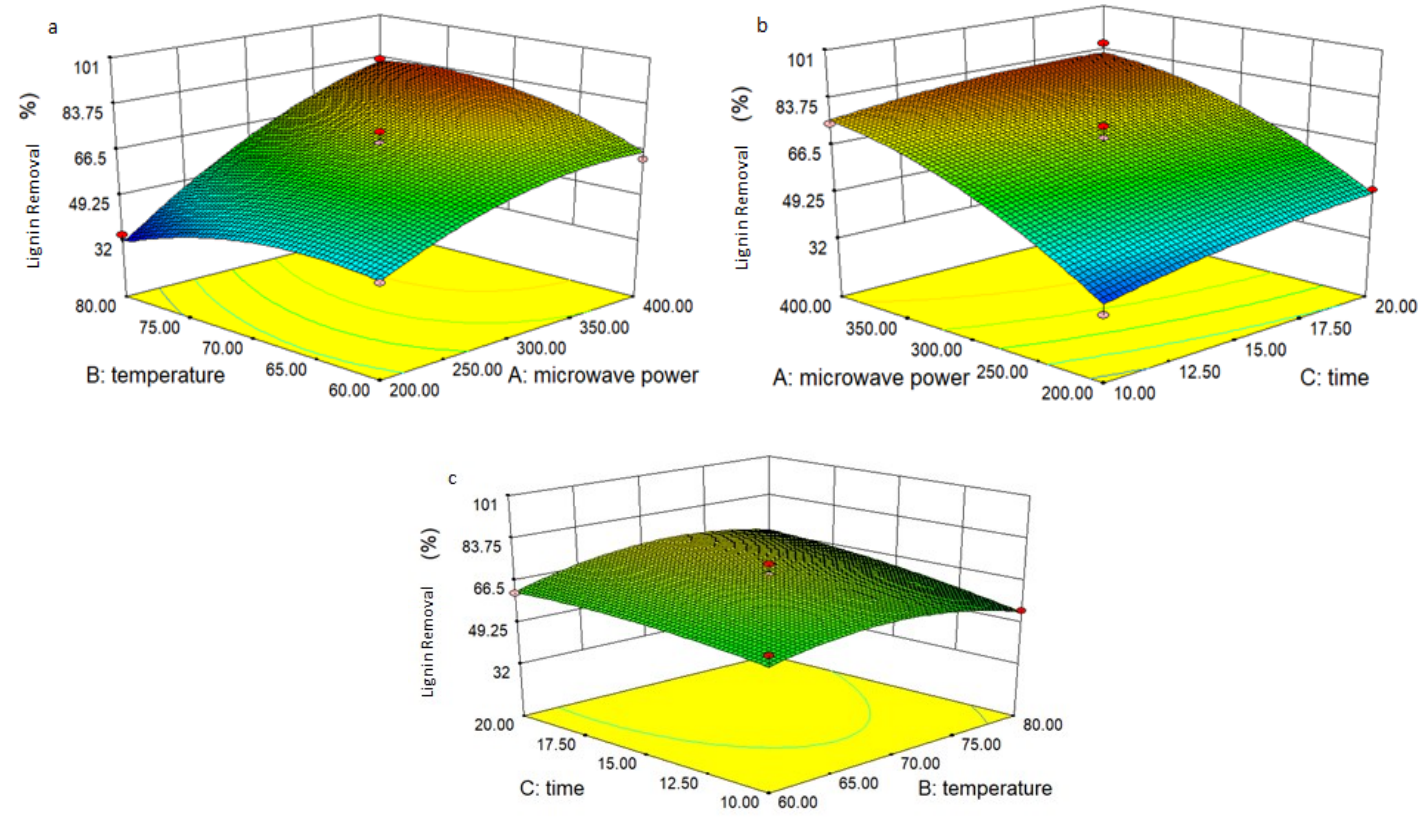

Fig. 3: RSM 3D plots of interaction between (a) microwave power and temperature, (b) microwave power and irradiation time and (c) microwave temperature and irradiation time in removing lignin from $\mathrm{CSW}$ in the presence of $\mathrm{NaOH}$.

\subsubsection{Thermogravimetric Analysis (TGA)}

Thermogravimetric analyses were performed to observe any change in thermal degradation profile of CSW after the treatment. Fig. 4 exhibits the TGA result of raw CSW and treated CSW. The weight of both samples firstly dropped until the temperature $120^{\circ} \mathrm{C}$ due to removal of unbound and bound water [24] or also known as drying period [25]. When heating temperature reached $230^{\circ} \mathrm{C}$, components which are believed [26] hemicellulose and cellulose started to decompose. Finally, different dropping trend possessed by raw CSW at higher temperature indicating that lignin content in the treated CSW has been decreased [26]. After analysis, it was found that the residual weight of raw CSW 11\% lower compare to raw CSW. When the treated fibres were subjected to heat, less chars were generated and resulting in lower amount of residual weight [27].

\subsubsection{Scanning Electron Microscopy (SEM)}


The changes in morphology of CSW were observed using scanning electron microscopy (SEM). Fig. 5 shows the significant effect of microwave of the alkali treatment of CSW. The surface of treated CSW in Fig. 5(b) seems rougher as compared to un-treated CSW in Fig. 5(a). The result is supported by the study carried out by Pua et al. [28] who found similar morphology result when they treated cocoa pod husk $(\mathrm{CPH})$ using the same alkaline. During their treatment, hemicellulose component including lignin had been removed and left mesoporous structure on the surface. The rough surface may provide more surface area for adhesion.

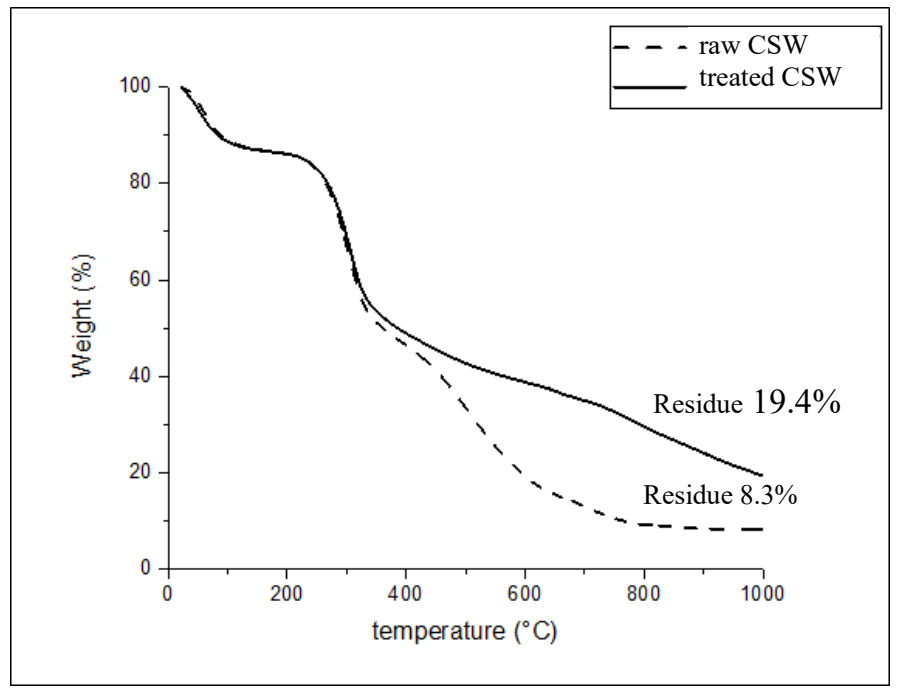

Fig. 4: Thermogravimetric analysis result for both CSW.

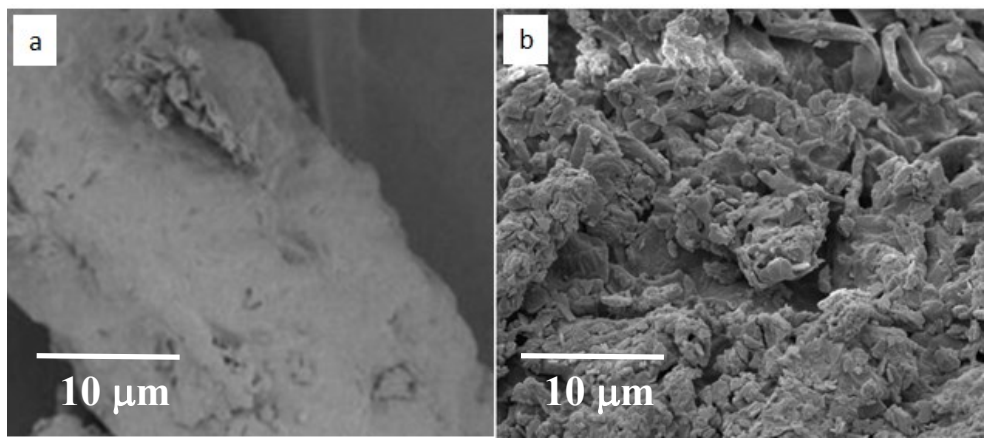

Fig. 5: SEM image with 2000 magnification for (a) untreated CSW sample and (b) treated CSW sample.

\section{CONCLUSION}

A microwave-assisted alkali treatment process is an alternative approach in quickly breaking the structure and removing lignin from CSW for preparation of bio composites. This approach is simple, easy and rapid. The results are successfully modelled using BoxBehnken design in the response surface methodology. The maximum removal of lignin up to $86.57 \%$ was obtained at the microwave power, temperature and irradiation time of 400 watt, $76^{\circ} \mathrm{C}$, and $19 \mathrm{~min}$, respectively. Removal of components within lignin decomposing temperature and change of CSW surface were shown by TGA and SEM analyses, respectively. 


\section{ACKNOWLEDGEMENT}

The authors are thankful for financial assistance by Ministry of Higher Education, Malaysia under research grants number: FRGS/1/2016/TK02/UMP/02/6 (RDU160126), Lembaga Koko Malaysia, Jerantut, Pahang, Malaysia for material supply, Universiti Malaysia Pahang under the grant number PGRS1903125 and Faculty of Chemical and Process Engineering Technology laboratory staff, UMP for technical support and facilities.

\section{REFERENCES}

[1] Balentic JP, Ačkar Đ, Jokic S, Jozinovic A, Babic J, Miličevic B, Ubaric D, Pavlovic N. (2018) Cocoa shell: A by-product with great potential for wide application. Molecules, 23 (6): 1-14. doi: 10.3390/molecules23061404.

[2] Handojo L, Triharyogi H, Indarto A. (2019) Cocoa bean shell waste as potential raw material for dietary fiber powder. Int $\mathrm{J}$ Recycl Org Waste Agric., 8: 485-491. doi: 10.1007/s40093-019-0271-9

[3] Jokić S, Gagić T, Knez E, Ubarić D, Kerget M. (2018) Separation of active compounds from food by-product (Cocoa Shell) using subcritical water extraction. Molecules, 23(6): 1408. doi: 10.3390/molecules23061408

[4] Fioresi F, Vieillard J, Bargougui R, Bouazizi N, Fotsing PN, Woumfo ED, Brun N, Mofaddel N, Le Derf F. (2017) Chemical modification of the cocoa shell surface using diazonium salts. Journal of Colloid and Interface Science, 494: 92-97. doi: 10.1016/j.jcis.2017.01.069.

[5] Foon CS, May CY, Liang YC, Ngan MA, Basiron Y. (2005) Palm biodiesel: Gearing towards Malaysian biodiesel standards. Palm oil developments (POD) 42: 28-34.

[6] Rojo-Poveda O, Barbosa-Pereira L, Zeppa G, Stévigny C (2020) Cocoa bean shell—a byproduct with nutritional properties and biofunctional potential. Nutrients 12(4): 1-29. doi: $10.3390 /$ nu12041123.

[7] Mohammed L, Ansari MNM, Pua G, Jawaid M, Islam MS. (2015) A review on natural fiber reinforced polymer composite and its applications. Int J Polym Sci. 243947. doi: $10.1155 / 2015 / 243947$

[8] Balaji A, Karthikeyan B, Sundar Raj C (2015) Bagasse fiber - The future biocomposite material: A review. Int. J. ChemTech Res, 7 (1): 223-233.

[9] Sood M, Dwivedi G. (2018) Effect of fiber treatment on flexural properties of natural fiber reinforced composites: A review. Egypt J Pet., 27(4): 775-783. doi: 10.1016/j.ejpe.2017.11.005

[10] Husseinsyah S, Marliza MZ, Selvi E. (2014) Biocomposites from polypropylene and corn cob: Effect maleic anhydride grafted polypropylene. Advances in materials Research, 3(3): 129-137.

[11] Laghari SM. Isa MH, Abdullah A, Laghari AJ, Saleem H. (2014) Microwave individual and combined pre-treatments on lignocellulosic biomasses. IOSR J Eng., 4(2): 14-28. doi: 10.9790/3021-04261427

[12] Nomanbhay SM, Hussain R, Palanisamy K. (2013) Microwave-assisted alkaline pretreatment and microwave assisted enzymatic saccharification of oil palm empty fruit bunch fiber for enhanced fermentable sugar yield. Journal of Sustainable Bioenergy Systems, 3(1): 7-17. doi: 10.4236/jsbs.2013.31002.

[13] Kucharska K, Rybarczyk P, Hołowacz I, Łukajtis R, Glinka M, Kamiński M. (2018) Pretreatment of lignocellulosic materials as substrates for fermentation processes. Molecules 23(11): 1-32. doi: 10.3390/molecules23112937.

[14] Rajesh M, Pitchaimani J, Rajini N. (2016) Free Vibration characteristics of banana/sisal natural fibers reinforced hybrid polymer composite beam. Procedia Engineering, 144: 1055-1059. doi: 10.1016/j.proeng.2016.05.056. 
[15] Budiyono, Wicaksono A, Rahmawan A, Hawali Abdul Matin H, Gumilang Kencana Wardani L, Djoko Kusworo T, Sumardiono S. (2017) The effect of pretreatment using sodium hydroxide and acetic acid to biogas production from rice straw waste. MATEC Web Conf. doi: 10.1051/matecconf/201710102011

[16] Modenbach AA, Nokes SE. (2014) Effects of sodium hydroxide pretreatment on structural components of biomass. Transactions of the ASABE, 57(4): 1187-1198. doi: $10.13031 / \operatorname{trans} .57 .10046$.

[17] Sombatpraiwan S, Junyusen T, Treeamnak T, Junyusen P. (2019) Optimization of microwave-assisted alkali pretreatment of cassava rhizome for enhanced enzymatic hydrolysis glucose yield. Food and Energy Security (October 2018): e00174. doi: $10.1002 /$ fes3.174.

[18] Agu OS, Tabil LG, Meda V, Dumonceaux T, Mupondwav E. (2019) Pretreatment of Crop Residues by Application of Microwave Heating and Alkaline Solution for Biofuel Processing: A Review. Renew Resour Biorefineries. doi: 10.5772/intechopen.79103

[19] Ethaib S, Omar R, Mazlina M, Radiah A, Syafiie S, Harun MY. (2016) Effect of microwave-assisted acid or alkali pretreatment on sugar release from Dragon fruit foliage. Int. Food Res. J., 23 (Suppl): S149-S154

[20] Safari A, Karimi K, Shafiei M. (2017) Dilute alkali pretreatment of softwood pine: A biorefinery approach. Bioresource Technology, 234: 67-76. doi: 10.1016/j.biortech.2017.03.030.

[21] Lai L, Idris A, Yusof NM. (2014) Lignin extraction from oil palm trunk by microwavealkali technique. Malaysian Journal of Fundamental and Applied Sciences, 10(2): 59-64.

[22] Duan D, Ruan R, Wang Y, Liu Y, Dai L, Zhao Y, Zhou Y, Wu Q. (2018) Microwaveassisted acid pretreatment of alkali lignin: Effect on characteristics and pyrolysis behavior. Bioresour. Technol., 251: 57-62. doi: 10.1016/j.biortech.2017.12.022

[23] Vardhini KJV, Murugan R, Selvi CT, Surjit R. (2016) Optimisation of alkali treatment of banana fibres on lignin removal. Indian Journal of Fibre and Textile Research, 41: 156-160.

[24] Yang H, Yan R, Chen H, Zheng C, Lee DH, Liang DT. (2006) In-depth investigation of biomass pyrolysis based on three major components: Hemicellulose, cellulose and lignin. Energy \& Fuels, 20(1): 388-393. doi: 10.1021/ef0580117.

[25] Sushmitha D, Suranai S. (2019) Microwave-assisted alkali-peroxide treated sawdust for delignification and its characterisation. in: Waste Valoris. Recycl. Singapore, Springer Singapore. pp 527-537.

[26] Waters CL, Janupala RR, Mallinson RG, Lobban LL. (2017) Staged thermal fractionation for segregation of lignin and cellulose pyrolysis products: An experimental study of residence time and temperature effects. Journal of Analytical and Applied Pyrolysis, 126: 380-389. doi: 10.1016/j.jaap.2017.05.008.

[27] Yew BS, Muhamad M, Mohamed SB, Wee FH. (2019) Effect of alkaline treatment on structural characterisation, thermal degradation and water absorption ability of coir fibre polymer composites. Sains Malaysiana, 48(3): 653-659. doi: 10.17576/jsm-2019-4803-19.

[28] Pua FL, Sajab MS, Chia CH, Zakaria S, Rahman IA, Salit MS. (2013) Alkaline-treated cocoa pod husk as adsorbent for removing methylene blue from aqueous solutions. Journal of Environmental Chemical Engineering, 1(3): 460-465. doi: 10.1016/j.jece.2013.06.012. 